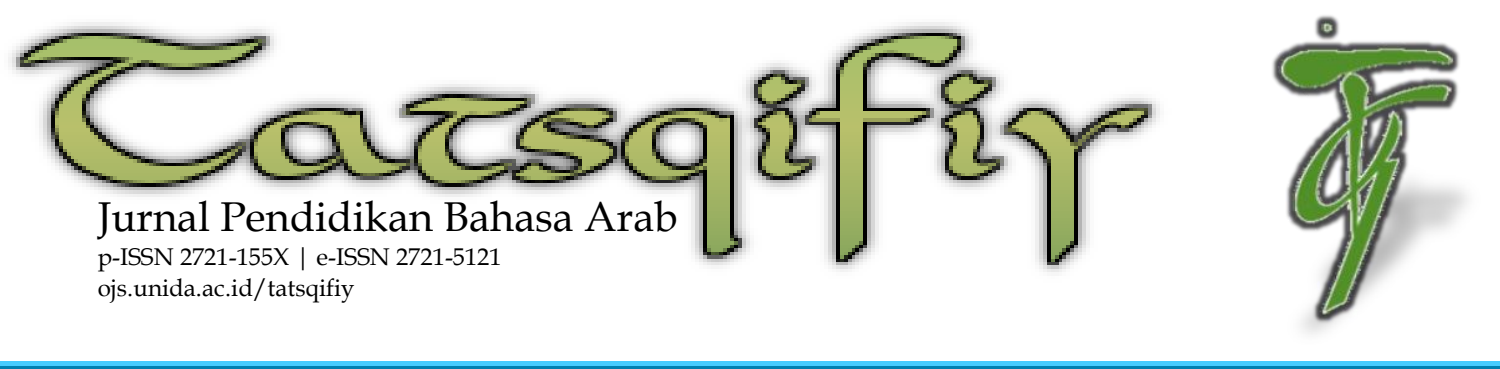

\title{
Analisis Kesesuaian Indikator dan Kompetensi Dasar Bahasa Arab KMA 183
}

\author{
Muhammad Jundi ${ }^{1}$, Najamudin Petta Solong ${ }^{1}$ \\ ${ }^{1}$ Pendidikan Bahasa Arab, Fakultas Ilmu Tarbiyah dan Keguruan \\ Institut Agama Islam Negeri Sultan Amai Gorontalo
}

Volume 2 Nomor 1

Januari 2021: 61-70

DOI: $10.30997 /$ tjpba.v2i1.3642

Article History

Submission: 10-10-2020

Revised: 12-11-2020

Accepted: 30-12-2020

Published: 28-01-2021

Kata Kunci: kompetensi dasar,_indikator, bahasa Arab, KMA 183

Keywords: basic competence, indicators, Arabic language, KMA 183

Korespondensi:

(Muhammad Jundi)

(085340076021)

(jundijundi10@gmail.com)
Abstrak: Munculnya KMA 183 dan penerapannya pada tahun ajaran 2020/2021 membawa banyak hal yang baru dan berbeda. Maka, madrasah yang dalam hal ini guru harus melakukan penyesuaian dalam hal perangkat pembelajaran PAI dan bahasa Arab. Penelitian ini menggunakan metode pengumpulan data dokumentasi. Dokumen-dokumen berupa RPP dan perangkat pembelajaran lainnya ditelaah dan bandingkan dengan isi KMA 183. Ditemukan bahwa guru bahasa Arab dalam mengembangkan indikator dari kompetensi dasar yang ada belum maksimal. Terlihat dari belum sesuainya indikator dengan kompetensi dasar yang berada pada tingkat berpikir C4. Guru masih menggunakan kata kerja operasional yang tidak relevan dengan kompetensi dasar yang ada. Diharapkan kedepannya lebih banyak lagi sosialisasi kepada guru dalam hal penyusunan perangkat pembelajaran khususnya dalam pengembangan indikator pembelajaran.

An Analysis of The Suitability of Indicators and Basic Competence in Arabic Through KMA 183

Abstract: The emergence of KMA 183 and its implementation in the 2020/2021 school year brought many new and different things. So, madrasah in this case the teacher must do adjustments in PAI and Arabic teachinglearning tools. This research uses the documentation data collection method. The documents in the form of lesson plans and other learning tools were reviewed and compared with the contents of KMA 183. It was found that Arabic teachers in developing indicators of existing basic competencies were not optimal. It can be seen from the inadequacy of indicators with basic competencies at the C4 thinking level. Teachers still use operational verbs that are not relevant to exist basic competencies. It is hoped that in the future there will be more socialization to teachers in terms of preparing learning tools, especially in developing learning indicators. 
PENDAHULUAN

Dalam mendidik, terdapat 3 hal yang mesti dikuasai oleh guru, yaitu kurikulum, proses pembelajaran, serta sistem penilaiannya (Febrian \& Fera, 2019). Sekilas ketiga hal tersebut terdengar mudah padahal sejatinya ada banyak sekali komponen di baliknya yang perlu diperhatikan. Sama halnya dengan mengajar, yang dilihat guru adalah menjelaskan dan memberi tugas. Akan tetapi di balik itu semua, guru disamping memberikan materi pembelajaran juga memberi nasehat dan membiasakan akhlak baik sehingga pendidikan dalam arti yang sebenarbenarnya mantap diberikan kepada peserta didik.

Dalam segi proses pembelajaran, ada berbagai macam keterampilan mengajar yang harus dikuasai. Terdapat beberapa keterampilan dasar yang harus diperhatikan dalam mengajar, yaitu: keterampilan mengajar seorang guru dalam membuka pelajaran, keterampilan menjelaskan, keterampilan mengadakan variasi mengajar, keterampilan bertanya, keterampilan memberikan penguatan, keterampilan mengelola kelas dan keterampilan menutup pelajaran (Wijarini \& Ilma, 2017).

Adapun kurikulum berkaitan erat dengan pembuatan perangkat pembelajaran seperti penyusunan rencana pelaksanaan pembelajaran. Adapun komponen-komponen dalam RPP meliputi tujuan pembelajaran, materi, metode/ model/ pendekatan/ strategi, sumber belajar /media, proses/kegiatan, alokasi waktu, dan evaluasi pembelajaran (Anggraeni, 2018).

Kegiatan penyusunan rencana pembelajaran merupakan salah satu tugas penting guru dalam pembelajaran. Dalam perspektif kebijakan pendidikan nasional yang dituangkan dalam Permendiknas RI No. 52 Tahun 2008 tentang Standar Proses disebutkan bahwa salah satu komponen dalam penyusunan RPP yaitu adanya tujuan pembelajaran yang didalamnya menggambarkan proses dan hasil belajar yang diharapkan dapat dicapai oleh peserta didik sesuai dengan kompetensi dasar (Mubin, 2018). Tujuan pembelajaran dalam RPP diambil dari indikator dan dirumuskan berdasarkan kompetensi dasar dan kompetensi inti. 
Pada tahun ajaran 2020/2021 mulai diterapkan KMA 183 sebagai perubahan dari KMA 165 tahun 2014. Maka konsekuensi dari hal itu, perangkat pembelajaran guru-guru pun harus disesuaikan dan diubah sesuai dengan apa yang ada pada KMA terbaru itu. Salah satu hal yang paling mudah diidentifikasi perbedaannya adalah dari segi muatan KD. Dalam mata pelajaran bahasa Arab sendiri terjadi banyak perubahan dalam muatan KD di setiap bab pembahasannya.

Madrasah Ibtidaiyah Muhammadiyah Pone sebagai salah satu madrasah ibtidaiyah yang berada di Limboto cukup tanggap dengan perubahan tersebut. Ditengah madrasah-madrasah lain masih menjalankan KMA 165, MIM Pone sudah memulai penerapannya pada tahun ajaran 2020/2021 walaupun ditengah pandemi. Guru-guru pada madrasah ini terbilang hampir selalu mengikuti bimbingan teknik guru-guru mata pelajaran dan tidak terkecuali dengan mata pelajaran bahasa Arab.

Dari latar belakang yang telah diuraikan di atas, tulisan ini hendak membahas tentang kesesuaian anatara indikator dan kompetensi dasar bahasa Arab KMA 183 tahun 2019.

\section{METODE}

Penelitian ini berjenis deskriptif dengan pendekatan kualitatif. Sebagaimana dijelaskan oleh Sukmadinata bahwa penelitian deskriptif merupakan penelitian yang bermaksud untuk memberikan deskripsi terhadap fenomena yang ada baik berupa bentuk, aktivitas, karakteristik, perubahan, hubungan, kesamaan, dan perbedaan antara fenomena yang satu dengan fenomena lainnya (Jundi \& Yasin, 2020). Jenis deskriptif cocok digunakan dalam penelitian ini sesuai dengan tujuannya yaitu untuk mendeskripsikan dan menggambarkan secara jelas dan ilmiah tentang kesesuaian antara indikator dan kompetensi dasar baru yang sesuai dengan KMA 183 tahun 2019.

Data dikumpulkan dengan dokumentasi. Dokumentasi maksudnya menggunakan dokumen-dokumen yang ada sebagai sumber informasi. Tidak hanya dapat menggunakan wawancara dan observasi tetapi informasi juga dapat diperoleh melalui fakta yang tersimpan dalam bentuk surat, catatan harian, arsip foto, hasil rapat, cenderamata, jurnal kegiatan dan 
sebagainya. Data berupa dokumen seperti ini dapat digunakan untuk mengulik infromasi dari masa lalu (Rahardjo, 2011). Dokumen yang dimaksud dalam penelitian ini adalah perangkat pembelajaran yang digunakan guru bahasa Arab dalam mengajar, mulai dari RPP, silabus, buku paket dan lain-lain.

Subjek penelitian ini adalah guru bahasa Arab di MIM Pone. Penulis melakukan analisis data dengan prosedur analisis data yang dikemukakan oleh Milles dan Huberman. Prosedur ini meliputi pengumpulan data, reduksi data, penyajian data, dan penarikan kesimpulan (Rijali, 2019). Dokumen RPP ditelaah dan dibandingkan dengan konten KMA 183 untuk mengetahui sesuai atau tidaknya.

\section{HASIL \& PEMBAHASAN}

Terdapat tiga domain dalam kompetensi dasar pada Kurikulum 2013, yaitu: afektif, kognitif, dan psikomotorik. Menurut Popham, ranah afektif adalah sesuatu yang berhubungan dengan emosi, perasaan, sikap hati, dan sistem nilai yang memperlihatkan penerimaan atau penolakan terhadap sesuatu, serta apresiasi dan penyesuaian perasaan (Rozak, 2014). Jadi, ranah afektif dalam pembelajaran berbicara tentang sikap, emosi, perasaan dan apresiasi seorang peserta didik terhadap segala sesuatu yang ada dalam pembelajaran itu sendiri baik itu terhadap sesama elemen pembelajaran maupun materi dan bahan ajar. Sementara itu, ranah kognitif adalah ranah yang berkaitan dengan hasil belajar intelektual yang meliputi enam aspek yaitu: pengetahuan atau ingatan, pemahaman, aplikasi, analisis, sintesis dan evaluasi Kemudian ranah psikomotorik adalah segala sesuatu yang berhubungan dengan aktifitas otot, fisik, atau gerakan-gerakan anggota badan. Keluaran hasil belajar yang bersifat psikomotorik adalah keterampilan-keterampilan gerak tertentu yang diperoleh setelah mengalami peristiwa belajar (Nurwati, 2014). Ketiga ranah tersebut samasama dikembangkan dalam kompetensi-kompetensi dasar Kurikulum 2013 yang diukur ketercapaiannya dengan indikator.

Langkah awal yang harus dilakukan pendidik dalam pengembangan indikator adalah 
menganalisis tingkat kompetensi yang ada pada Kompetensi Inti (KI) dan KD, yang dapat dilihat dari kata kerja operasionalnya (Scristia, 2019). Kata kerja operasional dalam dunia pendidikan sendiri banyak menggunakan tolok ukur taksonomi tingkatan berpikir khususnya dalam ranah kognitif yang dikemukakan oleh Benjamin Samuel Bloom dan kawankawan dalam buku mereka yang berjudul The Taxonomy of Educational Objectives The Classification of Educational Goals, Handbook I: Cognitive Domain. Kemudian muncul versi revisinya yang disusun oleh Loron $\mathrm{W}$. Anderson dan David R. Krathwohl dalam buku mereka yang berjudul $A$ Taxonomy for Learning, Teaching, and Assesing: A Revision of Bloom's Taxonomy of Educatioanl Objectives pada tahun 2001 (Gunawan \& Palupi, 2016). Menurut hemat penulis kemunculan versi revisi ini tentunya harus dilakukan mengingat buku pertama diterbitkan tahun 1950an. Sementara pendidikan adalah hal yang dinamis, dimana metode strategi dan tekniknya mesti senantiasa diperbarui menyesuaikan dengan perkembangan masyarakat di zaman sekarang.
Dalam penyusunan perangkat pembelajaran, hal pertama dilakukan guru adalah menganalisis kurikulum yang dalam hal ini berupa kompetensi dasar. Kompetensi dasar menurut Wina Sanjaya adalah perpaduan antara pengetahuan, keterampilan, nilai, dan sikap yang dimanifestasikan dalam kebiasaan berpikir dan bertindak. Adapun kompetensi dasar adalah kemampuan minimal yang harus dicapai peserta didik dalam penguasaan konsep atau materi pelajaran yang diberikan dalam kelas pada jenjang pendidikan tertentu. Dengan demikian dalam suatu mata pelajaran terdapat beberapa kompetensi dasar yang harus dicapai sebagai kriteria pencapaian standar kompetensi (Sanjaya, 2013). Sementara itu dengan mengutip pendapat Chamsiatin, Sa'dun Akbar menerangkan bahwa kompetensi dasar adalah kemampuan yang harus dimiliki peserta didik dalam mata pelajaran tertentu (Akbar, 2013). Pengertian ini sejalan dengan penjelasan Kunandar bahwa dalam konteks kurikulum yang berbasis kompetensi, kompetensi dasar merupakan kompetensi yang dipelajari 
siswa untuk suatu mata pelajaran di kelas tertentu (Kunandar, 2013). Berdasarkan uraian di atas, dapat dipahami bahwa kompetensi dasar adalah sesuatu yang harus dicapai dan dimiliki siswa untuk mencapai kompetensi inti. Kompetensi dasar yang ada pada setiap mata pelajaran semuanya akan bermuara kepada kompetensi inti.

Indikator hasil belajar adalah tujuan pembelajaran yang diharapkan dapat dimiliki oleh siswa setelah mereka melakukan proses pembelajaran tertentu. Dengan demikian indikator hasil belajar merupakan kemampuan siswa yang dapat diobservasi. Artinya apa hasil yang diperoleh siswa setelah mereka mengikuti proses pembelajaran (Sanjaya, 2013). Indikator harus kongkret sehingga pencapaian belajar dapat dengan mudah diidentifikasi dan diukur. Oleh karena itu, perumusan indikator-indikator dalam sebuah topik pembahasan menggunakan kata kerja operasional. Maka setelah itu materi pokok lah yang harus disesuaikan dengan indikator.

Adapun dalam penyusunan indikator seorang guru wajib memperhatikan pedoman yang didesain oleh Krathwohl yang merupakan revisi dari Bloom. Pertama, kompetensi dasar dikembangkan menjadi beberapa indikator. Kedua, indikator menggunakan kata kerja operasional. Ketiga, indikator dikembangan berdasarkan prinsip urgensi, kontinuitas, relevansi, dan kontekstual. Keempat, level kata kerja operasional dalam indikator minimal setara dengan kata kerja pada kompetensi dasar. Kelima, kata kerja operasional indikator harus berorientasi pada materi pokok, bukan pada tingkatan berpikir yang ada pada kata kerja dalam kompetensi dasar (Scristia, 2019).

Membahas tentang fungsi dan kegunaan indikator dalam kegiatan pembelajaran maka akan ditemukan banyak hal seperti telah dipaparkan sebelumnya bahwa indikator merupakan penanda pencapaian kompetensi dasar yang ditandai oleh perubahan perilaku siswa yang dapat diukur mencakup sikap pengetahuan dan keterampilan (Prastowo, 2015). Oleh karena itu, indikator menjadi kunci dari tolok ukur keberhasilan pembelajaran. Dimana indikator harus 
bersesuaian dengan materi yang

diberikan, kegiatan pembelajaran,

hingga pada penilaian pembelajaran.

Tabel 1 Analisis Indikator pada RPP Guru Bahasa Arab

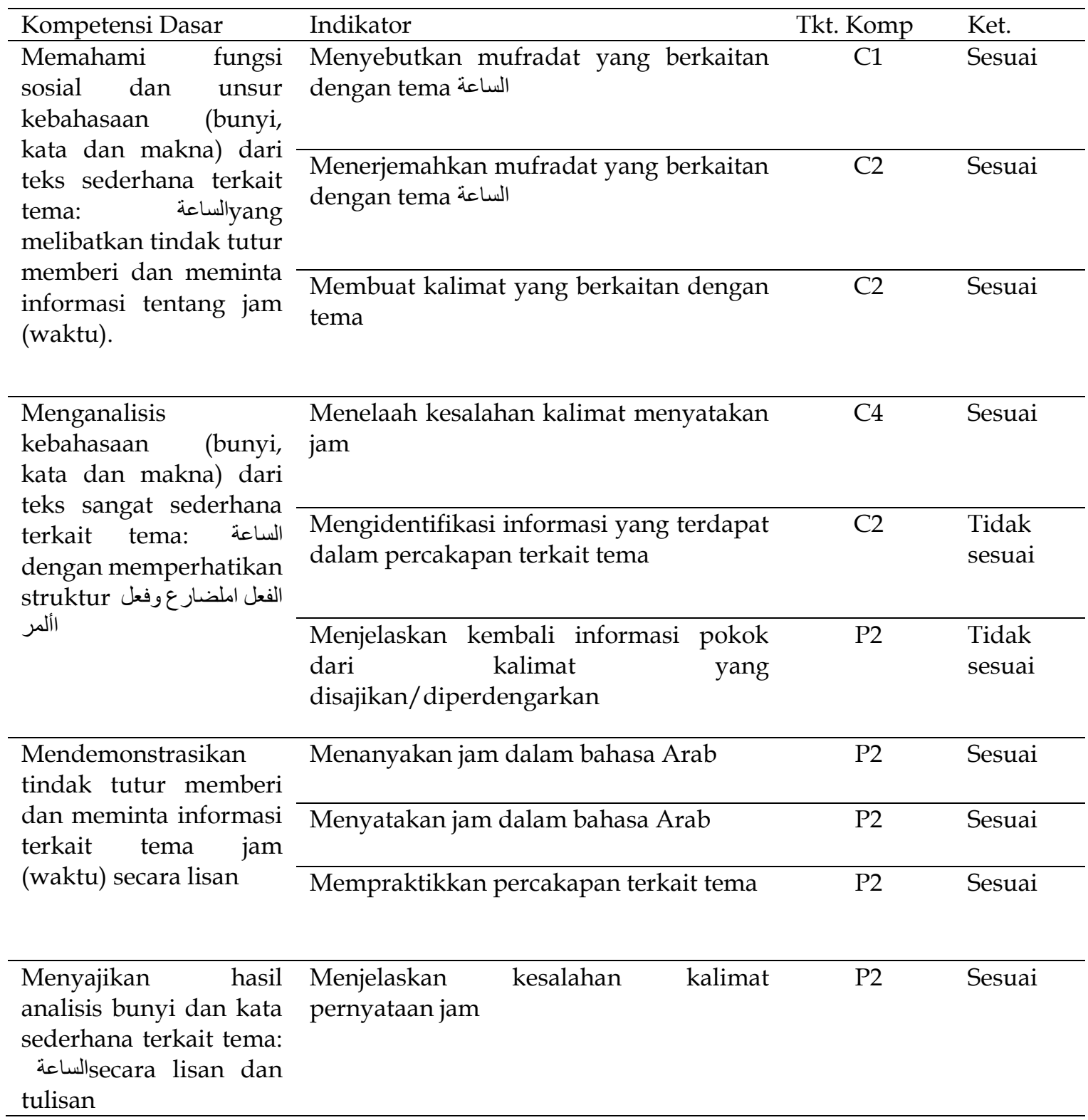

Berdasarkan hasil analisis terhadap indikator-indikator yang terdapat pada RPP guru bahasa Arab, ditemukan bahwa indikator-indikator yang dikembangkan dari kompetensi dasar 3.1 sesuai dengan tingkatan berpikir yang dimaksudkan. Melihat kompetensi dasarnya, dapat diketahui indikator yang disyaratkan adalah pada tingkat berpikir rendah. Seperti contohnya indikator Menerjemahkan mufradat yang berkaitan dengan tema 
yang berada pada tingkatan C2 (Pemahaman). Sebagaimana dijelaskan bahwa tingkatan C2 ini meliputi penerjemahan, interpretasi, dan ekstrapolasi (Gunawan \& Palupi, 2016).

Adapun untuk kompetensi dasar selanjutnya berada pada tingkatan berpikir $\mathrm{C} 4$ atau analisis. Dapat dilihat bahwa terdapat kata kerja operasional pada indikator yang tidak sesuai dengan tingkatan berpikir kompetensi dasarnya. Pada tingkatan menganalisis termasuk didalamnya penguraian masalah atau objek menjadi elemen penyusunnya lalu mencari tahu bagaimana keterkaitan antara elemen tersebut (Effendi, 2017). Pada tingkatan C4 seharusnya menggunakan kata kerja operasional seperti membuktikan, membedakan, mendiagnosis, mengedit, menelaah, dan sebagainya.

Kompetensi dasar psikomotorik berdasarkan RPP bahasa Arab sesuai dengan tingkatan berpikir psikomotorik yang disyaratkan. Sebagaimana dijelaskan oleh Mardapi, tahap-tahap keterampilan psikomotorik ada 6 tahap, yaitu: gerakan refleks, gerakan dasar, kemampuan perseptual, gerakan fisik, gerakan terampil, dan komunikasi nondiskursif. Jika dalam konteks pembelajaran bahasa, maka psikomotorik berkaitan erat dengan keterampilan berbahasa yang melibatkan gerakan anggota tubuh, seperti: berbicara, menjelaskan, bercakap-cakap, membuat projek, dan sebagainya.

\section{SIMPULAN}

Mengembangkan indikator dari kompetensi dasar yang ada mengharuskan guru untuk mampu menganalisis dan memahami klasifikasi tingkatan berpikirnya. Artinya guru juga wajib menguasai taksonomi tingkatan berpikir yang ada beserta penggunaan kata kerja operasionalnya. Adapun indikatorindikator yang dikembangkan oleh guru berdasarkan kompetensi dasar yang ada pada KMA 183 belum sepenuhnya sesuai. Untuk kompetensi dasar pada tingkatan berpikir rendah sudah sesuai tetapi tidak demikian dengan kompetensi dasar pada tingkatan berpikir tinggi. Berbeda dengan sebelumnya, kompetensi dasar KMA 183 yang diterapkan di MI sekarang memuat kompetensi yang berada pada tingkatan berpikir tinggi yaitu menganalisis. Sehingga guru perlu memodifikasi indikator- 
indikatornya sesuai dengan

kompetensi dasar yang disyaratkan.

\section{DAFTAR PUSTAKA}

Akbar, S. (2013). Instrumen Perangkat Pembelajran (3rd ed.). Remaja Rosdakarya.

Anggraeni, P. (2018). Analisis Keterkaitan Antar Komponen dalam Rencana Pelaksanaan Pembelajaran di Sekolah Dasar Kota Sumedang. El-Ibtidaiy:Journal of Primary Education, 1(1), 64. https://doi.org/10.24014/ejpe.v1i 1.5069

Effendi, R. (2017). Konsep Revisi Taksonomi Bloom dan Implementasinya pada Pelajaran Matematika SMP. JIPMat, 2(1). https://doi.org/10.26877/jipmat. v2i1.1483

Febrian, F., \& Fera, M. (2019). Kualitas Perangkat dan Keterampilan Mengajar Mahasiswa Pendidikan Matematika pada Mata Kuliah Micro Teaching Menggunakan Analisis Model Rasch. Jurnal Gantang, 4(1), 87-95. https://doi.org/10.31629/jg.v4i1. 1065

Gunawan, I., \& Palupi, A. R. (2016). Taksonomi Bloom - Revisi Ranah Kognitif: Kerangka Landasan untuk Pembelajaran, Pengajaran, dan Penilaian. Premiere Educandum: Jurnal Pendidikan Dasar Dan Pembelajaran, 2(02). https://doi.org/10.25273/pe.v2i0 2.50

Jundi, M., \& Yasin, Z. (2020). Penilaian Sejawat dalam Pembelajaran Keterampilan Dasar Mengajar bagi Mahasiswa Pendidikan Bahasa Arab pada Mata Kuliah Pembelajaran Mikro. Maharat: Jurnal Pendidikan Bahasa Arab, 2(2). https://doi.org/10.18196/mht.22 17

Kunandar. (2013). Penilaian Autentik (Penilaian Hasil Belajar Peserta Didik Berdasarkan Kurikulum 2013). RajaGrafindo Persada.

Mubin, H. (2018). Analisis Kompetensi Guru dalam Merencanakan dan Melaksanakan Pembelajaran Kimia Berbasis Kurikulum 2013 Studi Kasus di Kelas X SMA Negeri 6 Pontianak. AR-RAZI Jurnal Ilmiah, 6(2). https:/ / doi.org/10.29406/arr.v6i2.1223

Nurwati, A. (2014). Penilaian Ranah Psikomotorik Siswa dalam Pelajaran Bahasa. Edukasia: Jurnal Penelitian Pendidikan Islam, 9(2). https://doi.org/10.21043/edukasi a.v9i2.781

Prastowo, A. (2015). Menyusun Rencana Pelaksanaan Pmebelajaran (RPP) Tematik Terpadu Implementasi Kurikulum 2013 Untuk SD/MI (1st ed.). Prenada Media Group.

Rahardjo, M. (2011). Metode pengumpulan data penelitian kualitatif." Pascasarjana UIN Maulana Malik Ibrahim Malang. http:/ / repository.uinmalang.ac.id/1123/

Rijali, A. (2019). Analisis Data Kualitatif. Alhadharah: Jurnal Ilmu Dakwah, $\quad$ 17(33), 81. https:/ / doi.org/10.18592/alhadh arah.v17i33.2374

Rozak, P. (2014). Evaluasi Afektif dalam Pembelajaran. Madaniyah, 4(1), 5877.

Sanjaya, W. (2013). Perencanaan Dan Desain Pembelajran (6th ed.). Kencana Prenada Media Group.

Scristia, S. (2019). Analisis Kesesuaian Indikator terhadap Kompetensi Dasar pada Pelajaran Matematika 
oleh Guru Sekolah Menengah

Palembang. Jurnal Gantang, 4(2), 103-109.

https://doi.org/10.31629/jg.v4i2. 1429

Wijarini, F., \& Ilma, S. (2017). The Analysis of Teacher Candidates' Teaching Skill in Department of Biology Education, University of Borneo Tarakan, Through Preservice Teaching Activities. Jurnal Pendidikan Biologi Indonesia, 3(2), 149.

https://doi.org/10.22219/jpbi.v3i 2.4311 